\title{
Gender, Age and Anxiety as Predictors of Nomophobia in University Students*
}

\author{
İbrahim TAŞ $\quad$ Halime EKER ${ }^{* * *}$
}

\begin{abstract}
Mobile technologies have become one of the important parts of human life. Smartphones have become the most used technological devices of daily life, with newly added features every day. However, intense and non-functional use of these devices may cause problems. Nomophobia, which is defined as the fear of being without a mobile phone or being unable to be online, has begun to take place in literature as a current phenomenon. The present study discusses the variables of gender, age and anxiety as predictors of nomophobia in university students since the phenomenon is common especially in young people. The study group consists of 372 university students. Personal Information Form, Beck Anxiety Scale and Nomophobia scale were used as data collection tools in the study. Pearson correlational analysis and hierarchical regressions were conducted for data analysis. According to the results obtained from the study, anxiety total scale and subjective anxiety and somatic symptoms sub-dimensions were found to be positively associated with nomophobia. It was found that gender and subjective anxiety subdimension of anxiety scale significantly predicted nomophobia. On the other hand, it was found that the variable of age did not predict nomophobia significantly. The data obtained were discussed in the light of literature and suggestions were made to researchers.
\end{abstract}

Keywords: Nomophobia, Anxiety, University students, Gender.

\footnotetext{
${ }^{*}$ Ethics committee approval for this study was obtained from the Ethics Committee of İstanbul Sebahattin Zaim University, dated 04/09/2020 and numbered 2020/08.

** Orcid ID: https://orcid.org/0000-0002-5752-2753, Assoc. Prof. Dr., Sakarya University, Turkey, ibrahimtas34@gmail.com

*** Orcid ID: https://orcid.org/0000-0003-1801-3929, Assist. Prof. Dr., İstanbul Kültür University, Turkey, $\underline{\text { h.eker@iku.edu.tr }}$
} 


\section{INTRODUCTION}

Digital technologies make human life easier. Mobilization of digital technologies leads to these technologies' being available anytime and anywhere and therefore to their heavy use. Overuse of smartphones, which perform almost all functions of computers, can be problematic. One of these problems is nomophobia (King et al., 2013).

Mobile technology is an indispensable part of today's lifestyle (Adnan \& Gezgin, 2016). Increasing use of new technologies and virtual communications, including personal computers, tablets and mobile phones, is causing changes in daily habits and behaviors of individuals (King et al., 2013). As the development of information and communication technologies continues to advance rapidly, the use of mobile phones and smartphones increases significantly (Pivetta, Harkin, Billieux, Kanjo \& Kuss, 2019). "Anywhere and anytime" connection feature of mobile phones has eliminated the problem of distance between the individuals. In addition, smartphones which are used as mini computers have further increased the functionality of mobile phones (Kneidinger-Müller, 2019).

In recent years, lots of mobile applications have been developed and advanced features have been added to mobile phones. Smartphones which have these developed features and mobile applications facilitate the access to information and online services such as web browsing, access to social networks, entertainment, travel arrangements, ecommerce and banking (Gezgin, Hamutoğlu, Sezen-Gultekin \& Gemikonakli, 2018). While the use of smartphones facilitates the lives of individuals, some negative situations may occur due to excessive and problematic use such as addiction, anxiety, fear or restlessness (Konan, Durmuş, Türkoğlu \& Bakır, 2018). One of the disadvantages of the widespread use of smartphones is nomophobia (Gezgin, 2017).

Nomophobia was first described in 2008 as the fear of being separated from mobile phone (SecurEnvoy, 2012). Today, it is also called smartphone deprivation since smartphones have replaced traditional mobile phones (Gezgin et al., 2018). Nomophobia is considered a modern age phobia that has entered our lives as a by-product of the interaction between people, mobile information and communication technologies, especially smartphones (Yildirim \& Corriea, 2015).

The fact that individuals have smartphones with them everywhere can cause problems such as compulsive and addictive usage habits as well as communication and information overload. On the other hand, being without smartphones leads to basic psychological and social problems such as fears, emotional stress and feelings of social isolation (Kneidinger-Müller, 2019). Common behaviors among nomophobic individuals may be listed as follows (Bragazzi \& Del Puente, 2014): 1. Regular use of smartphone, spending too much time with the smartphone, having one or more smartphone, carrying a charger all the time, 2. Individual's feeling anxious and nervous at the thought of losing the smartphone, when the smartphone is no close or is out of the coverage area, when it cannot be used because of running out of charge or credit and avoiding places or situations where mobile phone use is prohibited, 3. Checking the phone screen to see whether messages or calls are taken or not, 4. Having the smartphone on throughout the 
day, sleeping with the smartphone, 5 . Having little face-to-face interaction with people who cause anxiety and stress and preferring communication using new technologies, 6 . Large amount of expenditure due to smartphone use.

It has been found that nomophobic individuals have increased heart rate, blood pressure levels and anxiety when they are away from their smartphone (Clayton, Leshner \& Almond, 2015). Nomophobia emerges as a threat to social and mental health as well as physical health. In this context, nomophobia is a kind of "over attachment syndrome" because excessive use of mobile phone decreases the amount of face-to-face communication and inhibits social and family interactions significantly (Bhattacharya, Bashar, Srivastava \& Singh, 2019). If the frequency of an individual's nomophobic behaviors increases, this affects the individual's academic performance, level of motivation during the learning process and relationships with family and peers negatively (Durak, 2018).

Studies on nomophobia are increasing day by day in literature. According to studies, some of the variables associated with nomophobia can be listed as the frequency and duration of smartphone use (Bivin, Mathew, Thulasi \& Philip, 2013; Gezgin, Şumuer, Arslan \& Yıldırım, 2017; Gezgin, Şahin \& Yıldırım, 2017; Hoşgör, Tandoğan \& GündüzHoşgör, 2017), loneliness and shyness (Bian \& Leung, 2014; Gezgin, Hamutoglu, SezenGultekin \& Ayas, 2018), social stress and lack of self-regulation (van Deursen, Bolle, Hegner \& Kommers, 2015), personality characteristics (Öz \& Tortop, 2018), social phobia (King et al., 2013; Uysal, Özen \& Madenoğlu, 2016; Apak \& Yaman, 2019), subjective well-being (Güllüce, Kaygın \& Börekçi, 2019), fear of missing social developments (Gezgin et al., 2018; Yaman \& Kavuncu, 2019) and social media addiction (Durak, 2018).

Anxiety is another variable nomophobia is associated with (Kara, Baytemir \& IncemanKara, 2019). Anxiety is a general worry about a possible future danger (Butcher, Mineka \& Hooley, 2013, p. 330) and the focus of anxiety is internal rather than external (Bourne, 2010, p. 6). Anxiety is defined as emotional reactions that are perceived as dangerous because they seem real, but are more likely to be at level of expectation because of their low probability of occurrence (Suadiye \& Aydın, 2009).

Anxiety is considered as a reaction to uncertain, remote and even unidentified dangers. Anxiety affects the individual's whole existence. Anxiety, which includes negative mood, feelings of inability to anticipate future danger or threats and inability to control these when they occur, chronic overstimulation and a tendency to avoid situations that may create danger, is also a physiological, behavioral and psychological reaction. At the physiological level, anxiety may include bodily reactions such as rapid heartbeat, muscle strain, nausea, sweating and dry mouth. At the behavioral level, anxiety may sabotage the individual's ability to move and express himself/herself or to cope with daily life situations. Psychologically, anxiety is a state of subjective worry and restlessness. In its most extreme form, anxiety may cause the individual to feel detached and even to fear, die or go crazy (Bourne, 2010, p. 6; Butcher et al., 2013, p. 333). 
Smartphone addiction, which was found to be associated with nomophobia (YildizDurak, 2019), was found to be positively associated with anxiety (Demirci, Akgönül and Akpınar, 2015; Elhai, Levine, Dvorak and Hall, 2016; Veerapu, Philip, Vasireddy, Gurrala and Kanna, 2019). In a study conducted by Hwang, Yoo and Cho (2012), individuals who used smartphones excessively experienced increased state anxiety and trait anxiety. Bian and Leung (2014) stated that individuals may tend to use smartphone more to avoid the feeling of anxiety. It is seen that nomophobia increases as the duration of smartphone use increases (Pavithra and Madhukumar, 2015; Erdem, Kalkın, Türen and Deniz, 2016; Erdem, Türen and Kalkın, 2017; Kaplan-Akıllı and Gezgin, 2016; Sırakaya, 2018). Kara et al. (2019) found a significant relationship between nomophobia and anxiety and stated that anxiety increasing with smartphone use causes nomophobic behaviors. A positive relationship was found between nomophobia and trait anxiety in a study conducted by Sezer and Yıldırım (2020).

The increase in nomophobia with the widespread use of smartphones in recent years suggests that more studies will be conducted on this concept day by day. Considering that smartphone use is most common among young people, nomophobia is a major threat to this population. For this reason, it is important to examine the variables associated with nomophobia. Nomophobic behaviors cause individuals' daily habits to change. In addition, students' school life and academic achievement may also be influenced by negativities caused by nomophobia (Adnan and Gezgin, 2016). The fact that nomophobia is a current phenomenon and affects students' personal, social and academic lives makes the study important. Therefore, the aim of this study is to examine whether anxiety predicts nomophobia.

In line with this purpose, the following sub-problems were examined.

1. Do age and gender predict nomophobia significantly in university students?

2. Does anxiety predict nomophobia significantly in university students?

\section{METHOD}

\section{Study Design}

The study has a correlational research design. Correlational research is an analysis method conducted to determine the level and direction of the relationship between variables, regardless of whether they are dependent or independent (Durmuş, Yurtkoru \& Çinko, 2011).

\section{Study Group}

Study group consists of 372 university students. 157 (42.2\%) of the participants are male, while 215 (57.8\%) are female. Participants' ages range between 18 and 33 and mean age is 20.31 . 


\section{Data Collection Tools}

\section{Nomophobia Scale}

In the study, the updated version of Nomophobia Scale as a 5-Likert type scale by Erdem et al. (2017), which was originally developed by Yildirim and Correia (2015) and adapted to Turkish culture by Yildirim, Sumuer, Adnan and Yildirim (2016), was used. In this version, items 8 and 12 were excluded from the scale since they were in more than one factor and thus a structure consisting of 18 items and 4 sub-dimensions (not being able to access information, being without the device, losing connection and not being able to be online). In the exploratory factor analysis, the scale was found to be grouped in 4 sub-dimensions and it was found that the factors explained $67.79 \%$ of the total variance in university students and $60.27 \%$ of the total variance in civil servants. Fit indices of both samples obtained as a result of the exploratory factor analysis (NFI:.907.903; NNFI: .948-.954; GFI:.905-.901; AGFI: .869-.850; RMSEA: .06-.06; CMIN/SD:2.1521.725 ) showed that the scale had a good fit. Reliability coefficient of the scale was found to be .92. In the present study, Cronbach-alpha internal consistency coefficient was found as .90 . This result shows that the scale was a reliable measurement instrument in this study (Kayış, 2014).

\section{Beck Anxiety Inventory}

The inventory developed by Beck, Epstein, Brown and Steer (1988) was adaptd to Turkish culture by Ulusoy, Şahin and Erkmen (1996). The scale consists of 21 items and two sub-dimensions (somatic symptoms and subjective anxiety). Construct validity of the inventory which is scored between 0 and 3, was tested with construct validity factor analysis. In the study conducted within the scope of criterion correlation validity, it was found to be associated with Automatic Thoughts Scale, Beck Depression Inventory, and State and Trait Anxiety Inventory. In the Cronbach alpha analysis conducted for scale reliability, internal consistency coefficient was found as .93, test-retest reliability was found as .57. Cronbach alpha internal consistency coefficient was found as .93 within the scope of this study (Kayış, 2014).

\section{Data Collection Analysis}

The data were collected online between September and October 2020. The data were collected from students studying at private/foundation and state universities on the European side of İstanbul by using appropriate sampling method, which is functional in terms of time, workforce and accessibility. Data were collected from the students on a voluntary basis. The students were told that they could leave the study at any point they liked. Ethics committee permission was taken for the study (İstanbul Sebahattin Zaim University Ethics Committee Approval (04/09/2020 dated and 2020/08 numbered ethics committee decision). Normality assumptions were examined before the data were analyzed. It was found that Kurtosis and Skewness values of the variables ranged between-.075 and-.881 and the data were normally distributed (Büyüköztürk, 2014). Gender variable was converted into a dummy variable because it was categorical. 
Female was coded as 1 and male was coded as 0 and the effect of being a female was analyzed. Next, the assumptions of multiple regression were tested. Multivariate normality and linearity scatter diagram matrix was examined and analyzed. The matrix was found to be distributed as an ellipsis. The fact that the matrix was in the shape of an ellipsis shows that the assumptions of normality and linearity were met (Çokluk, Şekercioğlu and Büyüköztürk, 2012). Multiple connection problem was examined by analyzing Variance Increase Factors (VIF) and it was found that these values were lower than 10 (1.018-2.863); therefore, no multiple connection problems were found (Çokluk et al., 2012). Durbin Watson statistics tests whether there is auto correlation, which is another assumption. Since the value obtained was between 1.5 and $2.5(\mathrm{dw}=2.045)$, it can be said that there was no auto correlation (Küçüksille, 2014). After it was seen that the assumptions were met, first correlation analysis was conducted, followed by hierarchical regression analysis. The data were analyzed with SPSS 25 package program

\section{FINDINGS}

Descriptive statistics of the variables and correlation analysis were performed and the results obtained are shown in Table 1.

Table 1

Descriptive statistics and Pearson Correlation Analysis results

\begin{tabular}{llllllllll}
\hline & M & Se & SD & S & K & NOMO & ANK & SS & SA \\
\hline NOMO & 66.11 & .79 & 15.24 & -.082 & -.110 & 1 & & & \\
ANT & 25.90 & .76 & 14.83 & .240 & -.770 & $.240^{* *}$ & 1 & & \\
SS & 9.83 & .30 & 5.82 & .148 & -.748 & $.192^{* *}$ & $.921^{* *}$ & 1 & \\
SA & 16.06 & .50 & 9.73 & .284 &.-881 & $.251^{* *}$ & $.973^{* *}$ & $.806^{* *}$ & 1 \\
\hline
\end{tabular}

${ }^{* *} \mathrm{p}<.01$

M: Mean; Se: Standard error; SD: Standard Deviation; K: Kurtosis, S: Skewness; NOMO: Nomophobia, ANT: Anxiety Total; SS: Somatic symptoms; SA: Subjective anxiety

When Table 1 is examined, it can be seen that nomophobia has a low positive significant correlation with anxiety $(\mathrm{r}=.240, \mathrm{p}<.01)$ and anxiety sub-dimensions somatic symptoms $(\mathrm{r}=.192, \mathrm{p}<.01)$ and subjective anxiety $(\mathrm{r}=.251, \mathrm{p}<.01)$.

In the study, hierarchical regression analysis was conducted to find out whether nomophobia was predicted by age, gender and anxiety. Analysis results are shown in Table 2 . 
Table 2

Hierarchical regression analysis results regarding the prediction of nomophobia

\begin{tabular}{llllllll}
\hline Variable & $\mathrm{B}$ & $\begin{array}{l}\text { Standard } \\
\text { Error }\end{array}$ & $\boldsymbol{\beta}$ & $t$ & $p$ & $\begin{array}{l}\text { Paired } \\
\mathrm{R}\end{array}$ & $\begin{array}{l}\text { Partial } \\
\mathrm{R}\end{array}$ \\
\hline Constant & $\mathbf{7 2 . 5 5 0}$ & $\mathbf{9 . 4 9 2}$ & & $\mathbf{7 . 6 4 3}$ &. $\mathbf{0 0 0}$ & & \\
Age & -.560 & .458 & -.061 & -1.222 & .222 & -.098 & -.064 \\
Female & 8.542 & 1.549 & .277 & 5.516 & .000 & .285 & .276 \\
\hline 1st Block: $\mathrm{R}=.292 ; \mathrm{R}^{2}=.085 ;$ & $\Delta \mathrm{R}^{2}=.085 ; \mathrm{F}_{(2,369)}=17.171 ; \mathrm{p}<.001$ & & \\
\hline Constant & $\mathbf{6 4 . 5 1 8}$ & $\mathbf{9 . 4 3 4}$ & & $\mathbf{6 . 8 3 9}$ & .000 & & \\
Age & -.437 & .446 & -.049 & -.980 & .328 & -.098 & -.051 \\
Female & 8.323 & 1.506 & .270 & 5.529 & .000 & .285 & .277 \\
SS & -.127 & .214 & -.049 & -.594 & .553 & .192 & -.031 \\
SA & .431 & .128 & .275 & 3.371 & .001 & .251 & .173 \\
\hline 2nd Block: $\mathrm{R}=.376 ; \mathrm{R}^{2}=.141 ;$ & $\Delta \mathrm{R}^{2}=.056 ; \mathrm{F}_{(2,367)}=12.042 ; \mathrm{p}<.001$ & & \\
\hline
\end{tabular}

Table 2 shows to what extent age, gender and anxiety predict nomophobia. According to this table, the variables of age and gender analyzed in the first block predict nomophobia significantly $\left(\mathrm{F}_{(2,369)}=17.171, \mathrm{p}<.001 ; \mathrm{R}^{2}=.085\right)$. Of the variables in the first block, it can be seen that socio-demographic variable age does not predict nomophobia significantly, while gender predicts nomophobia significantly and both variables explain $8.5 \%$ of the variance regarding nomophobia. Anxiety sub-dimensions analyzed in the second block (somatic symptoms and subjective anxiety) predict nomophobia significantly $\left(\mathrm{F}_{(2,367)}=\right.$ 12.042, $\left.\mathrm{p}<.001 ; \mathrm{R}^{2}=.141 ; \Delta \mathrm{R}^{2}=.056\right)$. When the contributions of the sub-dimensions of anxiety, which were included in the analysis in the second block, to the model are examined separately, it can be seen that subjective anxiety predicts nomophobia significantly, while somatic symptoms does not predict nomophobia significantly. It can be seen that both sub-dimensions explain 5.6\% of the total variance regarding nomophobia. When the model created is evaluated as a whole, it can be seen that the variables in the model (gender, age, subjective anxiety and somatic symptoms) explain $14.1 \%$ of the total variance regarding nomophobia

\section{RESULTS, DISCUSSIONS AND SUGGESTIONS}

Since nomophobia is one of the current problems brought by technology, it is a phenomenon that is emphasized. The fact that it is a relatively new problem causes a limitation in studies conducted on nomophobia. Investigation of these problems created 
by smartphones that most people do not drop from their hands and the variables it is associated with is important in terms of understanding this new phenomenon. This study investigates whether sociodemographic variables such as age and gender and a mental health problem such as anxiety predict nomophobia. It was found that gender and subjective anxiety predicted nomophobia significantly.

The first research question of the study is whether age and gender predict nomophobia significantly. As a result of the regression analysis conducted, it was found that gender, in other words being a female, predicted nomophobia significantly, while age was not a significant predictor of nomophobia. When the literature is examined in terms of the variable of gender, it can be seen similar to the results of the study that nomophobia level is significantly higher in men when compared with women (Burucuoğlu, 2017; Erdem et al., 2017; Turan and İşçitürk, 2018). There are also studies in literature which show that nomophobia does not differ significantly in terms of gender (Adnan and Gezgin, 2016; Apak and Yaman, 2019). Studies (Aktaş and Yllmaz, 2017; Erdem et al., 2016) show that women spend more time than men with smartphones. It is seen in literature that nomophobia is positively correlated with daily phone use time (YazıclKabadayl and Kabadayl, 2020), checking the phone frequently and the rate of mobile internet use (Gezgin et al., 2017). When this result of the study is examined in the light of literature, it can be said that women's spending more time with their smartphones and their checking their phones frequently both for the purposes of using the internet and also for other purposes is more effective in the development of nomophobia in women when compared with men. When the literature is reviewed in terms of the variable of age, it can be seen similar to the results of this study that there are studies which show that nomophobia does not differ significantly in terms of the variable of age (Güllüce, Kaygın and Börekçi, 2019; Ramazanoğlu, 2020). On the other hand, there are also studies in literature which show that nomophobia differs significantly in terms of the variable of age (Arslan, Tozkoparan and Kurt, 2019; Yıldız, Çengel and Alkan, 2020). One of the reasons why the variable of age did not have a significant effect on the emergence of nomophobia in this study may be the fact that the ages of the participants in the study were close. In addition, the fact that young people of all ages have smartphone today, in other words, the fact that there is no age to have smartphone may have affected the variable of age not to have a significant effect.

The second sub-problem of the study is whether anxiety predicts nomophobia. It was found that subjective anxiety sub-dimension of the anxiety scale used in the study predicted nomophobia significantly positively, while somatic symptoms did not predict nomophobia significantly. In other words, it was found that subjective anxiety had a significant effect on the emergence of nomophobia. When the literature is reviewed, it can be seen that there are studies supporting the result of this study (Demirci et al., 2015; Elhai et al., 2016; Kara et al., 2019; Veerapu et al., 2019). Anxiety is defined as the state of a general concern felt for a possible future danger and may reveal the tendency of the individual to escape from the threatening situation (Butcher et al., 2013). Since 
long-term anxiety creates negative effects on the mental health of the individual, the individual cannot stand this feeling for a long time and may turn to different areas to get rid of this anxiety. Smartphones, which are owned by almost all individuals and which attract individuals from all walks of life with their features, can be a safe haven to get rid of this intense anxiety. In this context, it can be said that anxiety has an impact on the development of nomophobia.

As a conclusion, nomophobia, which is one of the problems that emerged with the introduction of technology into the lives of human beings, is significantly predicted by gender and subjective anxiety, and both variables explain nomophobia significantly. On the other hand, it can be seen that the variable of age does not have a significant effect on the emergence of nomophobia.

The study has some limitations. It was conducted on university students. For this reason, the results of the study can only be generalized with similar samples. Some recommendations were made in the study for researchers. The results of the study can be tested by repeating the study on different samples (adolescents and adults). Since the ages of the sample were close to each other in the study, the effect of the variable of age may not have been fully determined. For this reason, the effect of age can be found by comparing the nomophobia levels of individuals with different ages. Experts in the field (psychological counsellor, psychologists and psychiatrists) may plan studies to decrease the level of anxiety by considering the effects of anxiety on nomophobia. Psychological counsellors working in schools can include this variable in the session by considering the effects of anxiety in psycho-education studies they will plan for decreasing nomophobia.

\section{References}

Adnan, M., \& Gezgin, D. M. (2016). Modern çağın yeni fobisi: Üniversite öğrencileri arasında nomofobi prevalansı [A modern phobia: Prevalence of nomophobia among college students] Journal of Faculty of Educational Sciences, 49(1), 141-158.

Aktaş, H., \& Yılmaz, N. (2017). Üniversite gençlerinin yalnızlık ve utangaçlık unsurları açısından akıllı telefon bağımlılığı [Smartphone addiction in terms of the elements of loneliness and shyness of university youth]. International Journal of Social Sciences and Education Research, 3(1), 85-100.

Apak, E., \& Yaman, Ö. M. (2019). Üniversite öğrencilerinde nomofobi yaygınlı̆̆ı ve nomofobi ile sosyal fobi arasındaki ilişki: Bingöl Üniversitesi örneklemi [The prevalence of nomophobia among university students and nomophobia's relationship with social phobia: The case of Bingöl University]. Addicta: The Turkish Journal on Addictions, 6, 609-627. doi:10.15805/addicta.2019.6.3.0078

Arslan, H., Tozkoparan, S. B., \& Kurt, A. A. (2019). Öğretmenlerde mobil telefon yoksunluğu korkusunun ve gelişmeleri kaçırma korkusunun incelenmesi [Examination of nomophobia and fear of missing out among teachers]. Erzincan Üniversitesi Eğitim Fakültesi Dergisi, 21(3), 237-256. 
Beck, A. T., Epstein, N., Brown, G., \& Steer, R. A. (1988). An inventory gor measuring clinical anxiety: Psychometric properties. Journal of Consulting and Clinical Psychology, 56, 893897. doi: 10.1037/0022-006X.56.6.893

Bhattacharya, S., Bashar, M. A., Srivastava, A., \& Singh, A. (2019). NOMOPHOBIA: NO MObile PHone PhoBIA. Journal of Family Medicine and Primary Care, 8(4), 1297-1300. doi:10.4103/jfmpc.jfmpc 7119

Bian, M., \& Leung, L. (2014). Linking loneliness, shyness, smartphone addiction symptoms, and patterns of smartphone use to social capital. Social Science Computer Review, 1-19.

Bivin, J. B., Mathew, P., Thulasi, P. C., \& Philip, J. (2013). Nomophobia-do we really need to worry about? Reviews of Progress, 1(1), 1-5.

Bourne, E. J. (2010). The anxiety and phobia workbook. (Fifth edition). New York: MJF Books.

Bragazzi, N. L., \& Del Puente, G. (2014). A proposal for including nomophobia in the new DSM-V. Psychology Research and Behavior Management, 7, 155. https:// doi.org/10.2147/prbm.s41386.

Burucuoğlu, M. (2017). Meslek yüksekokulu öğrencilerinin nomofobi düzeyleri üzerinde bir araștırma A [Research on nomophobia levels of vocational college students]. Karabük Üniversitesi Sosyal Bilimler Enstitüsü Dergisi, 7(2), 482-489.

Butcher, J. N., Mineka, S., \& Hooley, J. M. (2013). Anormal psikoloji [Abnormal psychology]. İstanbul: Kaknüs Pub.

Büyüköztürk, Ș. (2014). Sosyal bilimler için veri analizi el kitabı: İstatistik, araştırma deseni, SPSS uygulamaları ve yorum [Data analysis handbook for social sciences: Statistics, research design, SPSS applications and interpretation]. Ankara: Pegem Akademi.

Clayton, R. B., Leshner, G., \& Almond, A. (2015). The extended iSelf: The impact of iPhone separation on cognition, emotion, and physiology. Journal of Computer-Mediated Communication, 20, 119-135.

Çokluk, Ö., Şekercioğlu, G., \& Büyüköztürk, Ş. (2012). Sosyal bilimler için çok değiş̧kenli istatistik: SPSS ve LISREL uygulamaları [Multivariate statistics for social sciences: SPSS and LISREL applications]. Ankara: Pegem Akademi.

Demirci, K., Akgönül, M., \& Akpınar, A. (2015). Relationship of smartphone use severity with sleep quality, depression, and anxiety in university students. Journal of Behavioral Addictions, $4(2), 85-92$.

Durak, H. Y. (2018). What would you do without your smartphone? Adolescents' social media usage, locus of control, and loneliness as a predictor of nomophobia. Addicta: The Turkish Journal on Addictions, 5(2),1-15.

Durmuş, B., Yurtkoru, S., \& Çinko, M. (2011). Sosyal bilimlerde SPSS ile veri analizi [Data analysis with SPSS in social sciences] (4. bs.). İstanbul: Beta Pub

Elhai, J. D., Levine, J. C., Dvorak, R. D., \& Hall, B. J. (2016). Fear of missing out, need for touch, anxiety and depression are related to problematic smartphone use. Computers in Human Behavior, 63, 509-516. doi:10.1016/j.chb.2016.05.079

Erdem, H., Kalkın, G., Türen, U., \& Deniz, M. (2016). Üniversite öğrencilerinde mobil telefon yoksunluğu korkusunun (nomofobi) akademik başarıya etkisi [The effects of no mobile phone phobia (nomofobi) on academic performance among undergraduate students]. Süleyman Demirel Üniversitesi İktisadi ve İdari Bilimler Fakültesi Dergisi, 21(3), 923-936. 
Erdem, H., Türen, U., \& Kalkın, G. (2017). Mobil telefon yoksunluğu korkusu (nomofobi) yayılımı: Türkiye'den üniversite öğrencileri ve kamu çalışanları örneklemi [No mobile phone phobia (nomophobia) prevalence: samples of undergraduate students and public employees from Turkey]. Bilişim Teknolojileri Dergisi, 10(1), 1-12.

Gezgin D. M, Şahin, Y. L., \& Yıldırım, S. (2017). Sosyal ağ kullanıcıları arasında nomofobi yaygınlığının çeşitli faktörler açısından incelenmesi [The investigation of social network users' nomophobia levels regarding to various factors]. Eğitim Teknolojisi Kuram ve Uygulama, 7(1), 1-15.

Gezgin, D. M. (2017). Exploring the influence of the patterns of mobile internet use on university students' nomophobia levels. European Journal of Education Studies, 3(6), 29-53. doi:10.5281/zenodo.572344

Gezgin, D. M. Hamutoglu, N. B., Sezen-Gultekin, G., \& Gemikonakli, O. (2018). Relationship between nomophobia and fear of missing out among Turkish university students. Cypriot Journal of Educational Science, 13(4), 549-561.

Gezgin, D. M., Hamutoglu, N. B., Sezen-Gultekin, G., \& Ayas, T. (2018). The relationship between nomophobia and loneliness among Turkish Adolescents. International Journal of Research in Education and Science, 4(2), 358-374.

Gezgin, D. M., Şumuer, E., Arslan, O., \& Yıldırım, S. (2017). Nomophobia prevalence among preservice teachers: A case of Trakya University. Trakya Üniversitesi Eğitim Fakültesi Dergisi, 7(1), 86-95.

Güllüce, A. Ç., Kaygın, E., \& Börekçi, N. E. (2019). Üniversite öğrencilerinin nomofobi düzeyi ile öznel iyi olma durumları arasındaki ilişkinin belirlenmesi: Ardahan örneği [Determination of the relationship between the level of nomophobia and subjective well-being of university students: ardahan case]. Hacettepe Üniversitesi Íktisadi ve İdari Bilimler Fakültesi Dergisi, 37(4), 651-673.

Hoşgör, H., Tandoğan, Ö., \& Gündüz-Hoşgör, D. (2017). Nomofobinin günlük akıllı telefon kullanım süresi ve okul başarısı üzerindeki etkisi: sağlık personeli adayları örneği [Effect of nomophobia on duration of daily smartphone usage and school success: the example of health personnel candidates]. Akademik Sosyal Araștırmalar Dergisi, 5(46), 573-595.

Hwang, K. H, Yoo, Y. S., \& Cho, O. H. (2012). Smartphone overuse and upper extremity pain, anxiety, depression, and interpersonal relationship among college students. The Journal of the Korea Contents Association, 12(10), 365-375.

Kaplan-Akıllı, G., \& Gezgin, D. M. (2016). Üniversite öğrencilerinin nomofobi düzeyleri ile farklı davranış örüntülerinin arasındaki ilişkilerin incelenmesi [Examination of relationship between university students' nomophobia levels and behavior patterns]. Mehmet Akif Ersoy Üniversitesi Eğitim Fakültesi Dergisi, 40, 51-69.

Kara, M., Baytemir, K., \& Inceman-Kara, F. (2019). Duration of daily smartphone usage as an antecedent of nomophobia: exploring multiple mediation of loneliness and anxiety. Behaviour \& Information Technology, 1-14. doi:10.1080/0144929X.2019.1673485.

Kayıș, A. (2014). Güvenirlik analizi [Reliability analysis]. Ş. Kalaycı (ed.), SPSS uygulamalı çok değişkenli istatistik teknikleri [SPSS applied multivariate statistical techniques] (pp. 403419). (6. Ed). Ankara: Asil Pub. 
King, A. L., Valença, A. M., Silva, A. C., Baczynski, T., Carvalho, M. R., \& Nardi, A. E. (2013). Nomophobia: Dependency on virtual environments or social phobia? Computers in Human Behavior, 29(1), 140-144.

Kneidinger-Mueller, B. (2019). When the smartphone goes offline: A factorial survey of smartphone users' experiences of mobile unavailability. Computers in Human Behavior, 98, 1-10.

Konan, N., Durmuş, E., Türkoğlu, D., \& Ağıroğlu Bakır, A. (2018). How is smartphone addiction related to interaction anxiety of prospective teachers? Education Sciences, 8, 186. doi:10.3390/educsci8040186

Küçüksille, E. (2014). Çoklu doğrusal regresyon modeli [Multiple linear regression model]. Ş. Kalaycı (Ed), SPSS uygulamalı çok değişkenli istatistik teknikleri [SPSS applied multivariate statistical techniques] (pp. 47-66) içinde. Ankara: Asil Yayıncllık.

Lee, K. E., Kim, S. H., Ha, T. Y., Yoo, Y. M., Han, J. J., Jung, J. H., \& Jang, J. Y. (2016). Dependency on smartphone use and its association with anxiety in Korea. Public Health Reports, 131, 411419.

Öz, H., \& Tortop, H. S. (2018). Üniversite okuyan genç yetişkinlerin mobil telefon yoksunluğu korkusu (Nomofobi) ile kişilik tipleri arasındaki ilişkinin incelenmesi [Investigation of university students' nomophobia levels between personality types]. e-Jurnal of New Media / Yeni Medya Elektronik Dergi - eJNM, 2(3),146-159.

Pavithra, M. B., \& Madhukumar, S. (2015). A study on nomophobia-mobile phone dependence, among students of a medical college in Bangalore. National Journal of Community Medicine, 6(3), 340-344.

Pivetta, E., Harkin, L., Billieux, J., Kanjo, E., \& Kuss, D. J. Problematic smartphone use: An empirically validated model. Computers in Human Behavior, 100, 105-117.

Ramazanoğlu, M. (2020). Öğretmen adaylarinin nomofobi düzeylerinin belirlenmesi [Determining the nomophobia levels of teacher candidates]. Ekev Akademi Dergisi, 81, 247 264.

SecurEnvoy, (2012). 66\% of the population suffer from Nomophobia the fear of being without their phone. Retrieved from https://www.securenvoy.com/en-gb/blog/66-population-suffernomophobia-fear-being-without-their-phone.

Sezer, Ö., \& Yıldırım, O. (2020). The relationship between nomophobia and trait anxiety, basic psychological needs, happiness in adolescents. International Journal of Human Sciences, $17(2), 535-547$.

Sırakaya, M. (2018). Ön lisans öğrencilerinin nomofobi düzeylerinin akıllı telefon kullanım durumlarına göre incelenmesi [Examination of associate students' nomophobia levels according to smartphone use]. Mersin Üniversitesi Eğitim Fakültesi Dergisi, 14(2), 714-727.

Suadiye, Y., \& Aydın, A. (2009). Anksiyete bozukluğu olan ergenlerde bilişsel hatalar [Cognitive errors in adolescents with anxiety disorders]. Klinik Psikiyatri Dergisi, 12(4), 172-179.

Turan, E. Z., \& İşçitürk, G. B. (2018). İlahiyat fakültesi öğrencilerinin nomofobi düzeylerinin çeşitli faktörler açısından incelenmesi [Examination of the nomophobia levels of the students of the Faculty of Theology in terms of various factors]. OPUS Uluslararası Toplum Araştırmaları Dergisi, 9(16), 1931-1950. doi:10.26466/opus.461523 
Türen, U., Erdem, H., \& Kalkin, G. (2017). Mobil telefon yoksunluğu korkusu (nomofobi) yayılımı: Türkiye'den üniversite öğrencileri ve kamu çalışanları örneklemi [No mobile phone phobia (nomophobia) prevalence: samples of undergraduate students and public employees from Turkey]. International Journal of Informatics Technologies,10(1), 1-12. doi: $10.17671 /$ btd.30223

Ulusoy, M., Şahin, N., \& Erkmen, H. (1996). Turkish version of The Beck Anxiety Inventory: Psychometrik properties. Journal of Cognitive Psychotherapy, 12(2), 163-172.

Uysal, Ş., Özen, H., \& Madenoğlu, C. (2016). Social phobia in higher education: the influence of nomophobia on social phobia. The Global eLearning Journal, 5(2), 1-8.

van Deursen, A. J., Bolle, C. L., Hegner, S. M., \& Kommers, P. A. (2015). Modeling habitual and addictive smartphone behavior: The role of smartphone usage types, emotional intelligence, social stress, self-regulation, age, and gender. Computers in Human Behavior, $45,411-420$.

Veerapu, N., Philip, R. K. B., Vasireddy, H., Gurrala, S., \& Kanna, S. T. (2019). A study on nomophobia and its correlation with sleeping difficulty and anxiety among medical students in a medical college, Telangana. International Journal of Community Medicine And Public Health, 6(5), 2074-2076.

Yaman, Z., \& Kavuncu, B. (2019). Üniversite öğrencilerinin sosyal gelişmeleri kaçırma korkusunun ve sosyal ağ kullanım amacının nomofobi düzeyine etkisi [The effect of university students' fear of abduction of social developments and social networking purpose on nomophobia level]. Sosyal Bilimler Araştırmaları Dergisi, 14(2), 555-570.

Yazıcı-Kabadayı, S., \& Kabadayı, F. (2020). Nomofobiyi açılkamada psikolojik ihtiyaçlar ve günlük telefon kullanım süresinin rolü [The role of psychological needs and daily smartphone usage time to explain nomophobia]. Online Journal of Technology Addiction and Cyberbullying, 7(1), 1-20.

Yildirim, C., \& Correia A. P. (2015). Exploring the dimensions of nomophobia: Development and validation of a self-reported questionnaire. Computers in Human Behavior, 49, 130-137.

Yildirim, C., Sumuer, E., Adnan, M., \& Yildirim, S. (2016). A growing fear: Prevalence of nomophobia among Turkish college students. Information Development, 32(5), 13221331.

Yildiz Durak, H. (2019). Investigation of nomophobia and smartphone addiction predictors among adolescents in Turkey: Demographic variables and academic performance. The Social Science Journal, 56(4), 492-517.

Yıldız, E. P., Çengel, M., \& Alkan, A. (2020). Öğretmenlerin nomofobi düzeylerinin demografik özelliklerine ve akıllı telefon kullanım alışkanlıklarina göre incelenmesi [Investigation of teachers 'nomophobia levels according to demographic characteristics and smartphone use]. OPUS Uluslararası Toplum Araştırmaları Dergisi, 15(1), 5096-5120. 
Ethics committee approval for this study was obtained from the Ethics Committee of İstanbul Sebahattin Zaim University, dated 04/09/2020 and numbered 2020/08

\section{Statement of Contribution of Researchers to the Article:}

1st author contribution rate: $50 \%$

2nd author contribution rate: $50 \%$

\section{Conflict of Interest Statement:}

There is no conflict of interest.

Statement of Financial Support or Acknowledgment:

No financial support was received from any institution for this study. 


\title{
Üniversite Öğrencilerinde Nomofobinin Yordayıcıları Olarak Cinsiyet, Yaş ve Anksiyete*
}

\section{İbrahim TAŞ * $^{*}$}

\author{
Halime EKER $^{* * *}$
}

\begin{abstract}
Öz. Mobil teknolojiler insanoğlunun hayatının önemli parçalarından biri olmuştur. Her gün bir yenisi eklenen özellikleri ile akıllı telefonlar günlük hayatın en yoğun kullanılan teknolojik cihazları haline gelmeye başlamıştır. Ancak bu cihazların yoğun ve işlevsel olmayan kullanımı problemler yaratabilmektedir. Mobil telefonsuz kalma korkusu ya da çevrimiçi olamama korkusu olarak tanımlanan Nomofobi güncel bir olgu olarak alanyazında yer almaya başlamıştır. Olgunun özellikle gençlerde yaygın olması nedeniyle bu araştırmada üniversite öğrencilerinde nomofobinin yordayıcıları olarak cinsiyet, yaş ve anksiyete değişkenleri ele alınmıştır. Araştırma grubunu 372 üniversite öğrencisi oluşturmaktadır. Korelasyonel araştırma niteliğindeki çalışmada veri toplama araçları olarak Kişisel Bilgi Formu, Beck Anskiyete Ölçeği ve Nomofobi Ölçeği kullanılmıştır. Verilerin analizinde Pearson korelasyon analizi ve hiyerarşik regresyon analizleri yapılmıştır. Çalışmadan elde edilen sonuçlara göre anksiyete toplam puanı ile sübjektif anksiyete ve somatik semptomlar alt boyutları nomofobi ile pozitif ilişkili bulunmuştur. Cinsiyet ile anksiyete ölçeği sübjektif anksiyete alt boyutunun nomofobiyi anlamlı bir şekilde yordadığı tespit edilmiştir. Buna karşın yaş değişkeninin nomofobiyi anlamlı bir şekilde yordamadığı tespit edilmiştir. Elde edilen veriler alan yazın ışığında tartışılmış ve araştırmacılara önerilerde bulunulmuştur.
\end{abstract}

Anahtar Kelimeler: Nomofobi, Anksiyete, Üniversite Öğrencileri, Cinsiyet

\footnotetext{
* Bu çalışma için etik kurul izni 04/09/2020 tarih ve 2020/08 sayılı İstanbul Sebahattin Zaim Üniversitesi Rektörlüğü Etik Kurulu'ndan alınmıştır.

** Orcid ID: https://orcid.org/0000-0002-5752-2753, Doç. Dr., Sakarya Üniversitesi, Türkiye, ibrahimtas34@gmail.com

${ }_{* * *}$ Orcid ID: https://orcid.org/0000-0003-1801-3929, Dr. Öğr. Üyesi, İstanbul Kültür Üniversitesi, Türkiye, h.eker@iku.edu.tr
} 


\section{GİRIŞ}

Dijital teknolojiler insanoğlunun hayatını kolaylaştırmaktadır. Dijital teknolojilerin mobilleşmesi, bu teknolojilerin her zaman ve her yerde ulaşılabilir olmasını, dolayısıyla yoğun kullanımını beraberinde getirmektedir. Bilgisayarların neredeyse tüm işlevlerini yerine getiren akıllı telefonların aşırı kullanımı problemli olabilmektedir. $\mathrm{Bu}$ problemlerden biri de nomofobidir (King ve diğerleri, 2013).

Mobil teknoloji günümüz yaşam tarzının ayrılmaz bir parçasıdır (Adnan ve Gezgin, 2016). Kişisel bilgisayarların, tabletlerin ve cep telefonlarının dahil olduğu yeni teknolojilerin ve sanal iletişimin artan kullanımı, bireylerin günlük alışkanlıklarında ve davranışlarında değişikliklere neden olmaktadır (King ve diğerleri, 2013). Bilgi ve iletişim teknolojilerinin gelişimi hızlı bir biçimde ilerlemeye devam ettikçe cep telefonu ve akıllı telefonların kullanımı büyük ölçüde artmaktadır (Pivetta, Harkin, Billieux, Kanjo ve Kuss, 2019). Cep telefonlarının "her yerde ve her zaman" bağlantı özellikleri bireyler arasındaki mesafe sorununu ortadan kaldırmıștır. Bununla birlikte, mini bilgisayarlar olarak kullanılan akıllı telefonlar, cep telefonlarının işlevselliğini daha da arttırmıştır (Kneidinger-Müller, 2019).

Son yıllarda, bir dizi mobil uygulama geliştirilerek cep telefonlarına gelişmiş özellikler eklenmiştir. Bu gelişmiş özelliklere ve mobil uygulamalara sahip olan akıllı telefonlar, web'de gezinme, sosyal ağlara erişim, eğlence, seyahat düzenlemeleri, e-ticaret, bankacılık gibi bilgi ve çevrimiçi hizmetlere erişimi kolaylaştırmaktadır (Gezgin, Hamutoğlu, Sezen-Gultekin ve Gemikonakli, 2018). Akıllı telefonların kullanımı bireyin hayatını kolaylaştırırken, aşırı ve problemli kullanım nedeniyle, bağımlılık, endişe, korku veya huzursuzluk gibi bazı olumsuz durumlar da ortaya çlkabilmektedir (Konan, Durmuş, Türkoğlu ve Bakır, 2018). Akıllı telefonların yaygın kullanımının oluşturduğu dezavantajlardan biri de nomofobidir (Gezgin, 2017).

Nomofobi, ilk olarak 2008 yılında cep telefonundan ayrı kalma korkusu şeklinde tanımlanmıştır (SecurEnvoy, 2012). Günümüzde, akıllı telefonların geleneksel cep telefonlarının yerini almasından dolayı akıllı telefon yoksunluğu olarak da adlandırılmaktadır (Gezgin ve diğ., 2018). Nomofobi, insanlar, mobil bilgi ve iletişim teknolojileri, özellikle de akıllı telefonlar arasındaki etkileşimin bir yan ürünü olarak yaşamımıza giren bir modern çağ fobisi olarak kabul edilmektedir (Yildirim ve Corriea, 2015).

Akıllı telefonların her yerde bireyin yanında bulunması, iletişim ve aşırı bilgi yüklemenin yanı sıra kompulsif ve bağımlılık yapan kullanım alışkanlıkları gibi sorunlara neden olabilir. Diğer yandan, akıllı telefonların yokluğu korkular, duygusal stres, sosyal izolasyon duyguları gibi temel psikolojik ve sosyal sorunlara yol açmaktadır (Kneidinger-Müller, 2019). Nomofobik bireyler arasındaki ortak davranışlar şu şekilde sıralanabilir (Bragazzi ve Del Puente, 2014): 1. Akıllı telefonun düzenli olarak kullanılması, akıllı telefonla çok fazla zaman geçirilmesi, bir veya daha fazla akıllı telefona sahip olunması, her zaman şarj cihazı taşınması, 2. Bireyin akıllı telefonu kaybetme düşüncesiyle veya akıllı telefon yakın bir yerde olmadığında veya kapsama 
alanı dışında olma, şarjın veya kontörün bitmesi nedeniyle kullanılamadığında endişeli ve gergin hissetmesi ve cep telefonu kullanımının yasak olduğu yerlerden ve durumlardan kaçınması, 3. Mesajların veya çağrıların alınıp alınmadığını görmek için telefonun ekranına bakılması, 4. Akıllı telefonunun gün boyunca açık tutulması, akıllı telefonla birlikte uyunması, 5. Anksiyete ve strese yol açacak insanlarla yüz yüze çok az etkileşime geçilmesi ve yeni teknolojiler kullanılarak iletişimin tercih edilmesi, 6. Akıllı telefon kullanımı nedeniyle büyük miktarda harcama oluşması.

Nomofobik bireylerin akıllı telefondan ayrı kaldıklarında kalp atış hızı, kan basıncı seviyeleri ve kaygı durumlarında artış olduğu belirlenmiştir (Clayton, Leshner ve Almond, 2015). Nomofobi, fiziksel sağlı̆̆ın yanı sıra sosyal ve ruhsal sağlık için de bir tehdit olarak ortaya çıkmaktadır. Bu bağlamda Nomofobi, bir tür "aşırı bağlantı sendromu"dur, çünkü aşırı cep telefonu kullanımı yüz yüze etkileşimlerin miktarını azaltarak sosyal ve ailevi etkileşimleri önemli ölçüde engeller (Bhattacharya, Bashar, Srivastava ve Singh, 2019). Bireyin nomofobik davranışının sıklığı artarsa, bu akademik performansını, öğrenme sürecindeki motivasyon düzeyini ve aile ve akranlarıyla ilişkilerini olumsuz yönde etkilemektedir (Durak, 2018).

Alanyazında nomofobi ile ilgili çalışmalar günden güzen artmaktadır. Çalışmalara göre Nomofobi ile bağlantılı olan değişkenlerden bazıları, akıllı telefon kullanım sıklığı ve süresi (Bivin, Mathew, Thulasi ve Philip, 2013; Gezgin, Şumuer, Arslan ve Yıldırım, 2017; Gezgin, Şahin ve Yıldırım, 2017; Hoşgör, Tandoğan ve Gündüz-Hoşgör, 2017), yalnızlık ve utangaçlık (Bian ve Leung, 2014; Gezgin, Hamutoglu, Sezen-Gultekin ve Ayas, 2018;), sosyal stres ve öz-düzenleme yetersizliği (van Deursen, Bolle, Hegner ve Kommers, 2015), kişilik özellikleri (Öz ve Tortop, 2018), sosyal fobi (King ve diğ., 2013; Uysal, Özen ve Madenoğlu, 2016; Apak ve Yaman, 2019), öznel iyi oluş (Güllüce, Kaygın ve Börekçi, 2019), sosyal gelişmeleri kaçırma korkusu (Gezgin ve diğ., 2018; Yaman ve Kavuncu, 2019) ve sosyal medya bağımlılı̆̆ (Durak, 2018) olarak sıralanabilir.

Nomofobinin ilişkili olduğu bir diğer değişken anksiyetedir (Kara, Baytemir ve IncemanKara, 2019). Anksiyete, gelecekte gerçekleşecek olası bir tehlikeye ilişkin hissedilen genel endişedir (Butcher, Mineka ve Hooley, 2013, s. 330) ve anksiyetenin odağ dişsal olmasından daha çok içseldir (Bourne, 2010, s. 6). Anksiyete, gerçekmiş gibi görünmesi nedeniyle tehlikeli olduğu algılanan, ancak oluşma olasılığı çok düşük olduğu için daha çok beklenti düzeyinde olan duygusal tepkiler şeklinde tanımlanmaktadır (Suadiye ve Aydın, 2009).

Anksiyete, belirsiz, uzak ve hatta tanımlanamayan tehlikelere yönelik bir tepki olarak görülmektedir. Anksiyete bireyin bütün varlığını etkiler. Olumsuz duygu durumu, gelecekteki tehlikeyi ya da tehditleri öngörememe ve gerçekleştiğinde kontrol edememe duyguları, kronik aşırı uyarılma durumu ve tehlike oluşturabilecek durumlardan kaçınmaya yönelik bir eğilimin söz konusu olduğu anksiyete, aynı anda fizyolojik, davranışsal ve psikolojik bir reaksiyondur. Fizyolojik seviyede anksiyete, hızlı kalp atışı, kas gerginliği, mide bulantısı, terleme ve ağız kuruluğu gibi bedensel tepkileri içerebilir. Davranışsal düzeyde anksiyete, bireyin hareket ve kendini ifade etme yeteneğini veya 
günlük yaşam durumlarıyla başa çıkma becerisini sabote edebilir. Psikolojik olarak anksiyete, öznel bir endişe ve huzursuzluk durumudur. En uç şekliyle anksiyete, bireyin kendisinden kopmuş hissetmesine ve hatta korkmasına, ölmesine veya çıldırmasına bile neden olabilir. (Bourne, 2010, s. 6; Butcher ve diğ., 2013, s. 333).

Nomofobi ile ilişkili olduğu tespit edilen akıllı telefon bağımlılığının (Yildiz-Durak, 2019) anksiyete ile pozitif ilişkili olduğu tespit edilmiştir (Demirci, Akgönül ve Akpınar, 2015; Elhai, Levine, Dvorak ve Hall, 2016; Veerapu, Philip, Vasireddy, Gurrala ve Kanna, 2019). Hwang, Yoo ve Cho (2012) tarafından yapılan çalışmada, akıllı telefonları aşırı kullanan bireylerin artan durumluk anksiyete ve sürekli anksiyete yaşadıkları belirlenmiştir. Bian ve Leung (2014), bireylerin kaygı duygusundan kaçınmak amacıyla daha fazla akıllı telefon kullanma eğiliminde olabildiğini ifade etmiştir. Akıllı telefon kullanım süresi arttıkça nomofobinin de arttı̆̆ı görülmektedir (Pavithra ve Madhukumar, 2015; Erdem, Kalkın, Türen ve Deniz, 2016; Erdem, Türen ve Kalkın, 2017; Kaplan-Akıllı ve Gezgin, 2016; Sırakaya, 2018). Kara ve diğerleri (2019), nomofobi ve anksiyete arasında anlamlı bir ilişki olduğunu ve akıllı telefon kullanımı arttıkça yükselen kaygının nomofobik davranışlara neden olduğunu bulmuştur. Sezer ve Yıldırım (2020) tarafından yapılan çalışmada, nomofobi ile sürekli kaygı arasında pozitif ilişki olduğu görülmüştür.

Son yıllarda akıllı telefon kullanımının yaygınlaşmasıyla birlikte nomofobinin de artması, gün geçtikçe bu kavramla ilgili daha çok çalışmanın yapılacağını düşündürmektedir. Akıllı telefon kullanımının en çok gençler arasında yaygın olduğu dikkate alındığında, nomofobinin bu kuşak için büyük bir tehdit olduğu söylenebilir. Bu nedenle, nomofobinin ilişkili olduğu değişkenlerin incelenmesi önem taşımaktadır. Nomofobik davranışlar, bireylerin günlük alışkanlıklarının değişmesine neden olmaktadır. Bunun yanında, öğrencilerin okul yaşamları ve akademik başarıları da nomofobiden kaynaklanan olumsuzluklar nedeniyle etkilenebilmektedir (Adnan ve Gezgin, 2016). Nomofobi olgusunun güncel olması ve üniversite öğrencilerinin kişisel, sosyal ve akademik yaşamlarını etkiliyor olması, çalışmayı önemli kılmaktadır. Bu doğrultuda çalışmanın amacı, anksiyetenin nomofobiyi yordayıp yordamadığını incelemektir.

$\mathrm{Bu}$ amaç doğrultusunda aşağıdaki alt problemler araştırılmıştır.

1. Üniversite öğrencilerinde yaş ve cinsiyet nomofobiyi anlamlı bir şekilde yordamakta mıdır?

2. Üniversite öğrencilerinde anskiyete nomofobiyi anlamlı bir şekilde yordamakta midır?

\section{YÖNTEM}

\section{Araştırmanın modeli}

Araştırma korelasyonel araştırma türündedir. Korelasyonel araştırma, değişkenlerin bağımlı ya da bağımsız olmalarına bakmadan aralarındaki ilişkinin düzeyi ve yönünü belirlemek amacıyla yapılan analiz yöntemidir (Durmuş, Yurtkoru ve Çinko, 2011). 


\section{Araştırma grubu}

Araştırma grubunu 372 üniversite öğrencisi oluşturmaktadır. Katılımcıların 157'si (\%42.2) erkek, 215’i (\%57.8) kadındır. Katılımcıların yaş aralıkları 18-33 arasında olup yaş ortalamaları $20.31^{\prime}$ dir.

\section{Veri toplama araçları}

\section{Nomofobi ölçeği}

Araştırmada Yildirim ve Correia (2015) tarafından geliştirilen, Yildirim, Sumuer, Adnan ve Yildirim (2016) tarafından Türk kültürüne uyarlanan ölçeğin Erdem ve diğerleri (2017) tarafından 5'li likert türü olarak güncellenen versiyonu kullanılmıştır. Bu versiyonde 8 ve 12. Maddeler birden fazla faktçrde yer aldığı için ölçekten çıkarılmış böylecek 18 madde 4 alt boyuttan (Bilgiye ulaşamama, cihazdan yoksunluk, iletişim kaybetme ve çevrimiçi olamama) oluşan bir yapı elde ediilmiştir. Açımlayıcı faktör analizinde ölçeğin 4 alt boyutta toplandığı tespit edilmiş ve faktörlerin üniversite öğrencilerinde toplam varyansın \%67.79'unu, kamu çalışanlarında \%60.27'ini açıkladığı görülmüştür. Doğrulayıcı faktör analizi sonucu elde edilen her iki örnekleme ait uyum indeksleri (NFI:.907-.903; NNFI: .948-.954; GFI:.905-.901; AGFI: .869-.850; RMSEA: .06.06; CMIN/SD:2.152-1.725) ölçeğin iyi uyum verdiğini göstermektedir. Ölçeğe ilişkin güvenirlik katsayısı .92 ve üzerinde olduğu tespit edilmiştir. Bu araştırmada ölçülen Cronbach-alpha iç tutarlılık katsayısı .90 'dır. Bu sonuç, ölçeğin bu araştırmada oldukça güvenilir bir ölçme aracı olduğunu göstermektedir (Kayış, 2014)

\section{Beck anksiyete ölçeği}

Beck, Epstein, Brown ve Steer (1988) tarafından geliştirilen ölçek Ulusoy, Şahin ve Erkmen (1996) tarafından Türk kültürüne uyarlanmıştır. Ölçek 21 madde iki alt boyuttan (somatik semptomlar ve sübjektif anksiyete) oluşmaktadır. 0-3 arasında puanlanan ölçeğin yapı geçerliği faktör analizi ile test edilmiştir. Ölçüt bağıntı geçerliği kapsamında yapılan çalışmada Otomatik Düşünceler Ölçeği, Beck Depresyon Ölçeği, Durumluk ve Sürekli Kaygı Envanteri ile pozitif ilişkili olduğu tespit edilmiştir. Ölçeğin güvenirliği için yapılan Cronbach alpha analizinde iç tutarlılık katsayısı .93, test tekrar test güvenirliği ise .57 şeklinde tespit edilmiştir. Bu araştırma kapsamında tespit edilen Cronbach alpha iç tutarlılık katsayısı .93 olarak tespit edilmiştir (Kayış, 2014).

\section{Verilerin toplaması ve analizi}

Araştırmanın verileri Eylül ve Ekim 2020 tarihlerinde çevrimiçi olarak toplanmıştır. Veriler zaman, işgücü ve ulaşılabilirlik açısından işlevsel olan uygun örnekleme yöntemi ile İstanbu ili Avrupa yakasındaki özel/vakıf ve devlet üniversitelerinde öğrenim gören öğrencilerden toplanmıştır. Veriler öğrencilerden gönüllülük esasına göre toplanmıştır. Öğrencilere araştırmanın herhangi bir noktasında diledikleri zaman çalışmadan ayrılabilecekleri ifade edilmiştir. Araştırma için etik kurul izni alınmıştır (İstanbul Sebahattin Zaim Üniversitesi Etik Kurulu onayı (04/09/2020 tarih ve 2020/08 sayılı etik kurul kararı). Veriler analiz edilmeden önce normallik varsayımları incelenmiştir. Değişkenlere ait basıklık ve çarpıklık değerlerinin -.075 ile -.881 arasında yer aldığı ve 
verilerin normal dağıldığı tespit edilmiştir (Büyüköztürk, 2014). Cinsiyet değişkeni kategorik olduğu için dummy değişkene çevrilmiştir. Kadın 1 erkek 0 olarak kodlanmış ve kadın olmanın etkisine bakılmıştır. Daha sonra çoklu regresyonun varsayımları test edilmiştir. Çok değişkenli normallik ve doğrusallık saçılma diyagramı matrisi incelenerek araştırılmıştır. Matrisin elips şeklinde dağıldığı görülmüştür. Matrisin elips şeklinde olması çok değişkenli normallik ve doğrusallık varsayımlarının karşılandığını göstermektedir (Çokluk, Şekercioğlu ve Büyüköztürk, 2012). Çoklu bağlantı problemi Varyans Artış Faktörlerinin (VİF) incelenmesi ile araştırılmış ve bu değerlerin (1.0182.863) 10'dan küçük olduğu, çoklu bağlantı probleminin olmadığı görülmüştür (Çokluk ve diğerleri, 2012). Durbin Watson istatistiği ile bir diğer varsayım olan oto korelasyon olup olmadığı test edilmektedir. Elde edilen değer $(\mathrm{dw}=2.045)$ 1.5-2.5 arasında olduğundan oto korelasyon olmadığı söylenebilir (Küçüksille, 2014). Varsayımların karşılandığı görüldükten sonra öncelikle korelasyon analizi sonrasında hiyerarşik regresyon analizi yapılmıștır. Veriler SPSS 25 paket programı ile analiz edilmiştir.

\section{BULGULAR}

Değişkenlere ait betimsel istatistikler ve korelasyon analizi yapılmış ve elde edilen sonuçlar Tablo 1'de verilmiştir.

Tablo 1

Betimsel istatistikler ve Pearson Korelasyon analizi sonuçları

\begin{tabular}{llllllllll}
\hline & 0 & Sh & SS & CRR & BS & NOMO & ANK & SS & SA \\
\hline NOMO & 66.11 & .79 & 15.24 & -.082 & -.110 & 1 & & & \\
ANK & 25.90 & .76 & 14.83 & .240 & -.770 & $.240^{* *}$ & 1 & & \\
SS & 9.83 & .30 & 5.82 & .148 & -.748 & $.192^{* *}$ & $.921^{* *}$ & 1 & \\
SA & 16.06 & .50 & 9.73 & .284 &.-881 & $.251^{* *}$ & $.973^{* *}$ & $.806^{* *}$ & 1 \\
\hline
\end{tabular}

${ }^{* *} \mathrm{p}<.01$

O: Ortalama; Sh: Standart hata; SS: Standart Sapma; BS: Basıklık, ÇR: Çarpıklık; NOMO: Nomofobi, ANK: Anksiyete toplam; SS: Somatik semptomlar; SA: Subjektif anksiyete

Tablo 1 incelendiğinde nomofobinin anksiyete ( $\mathrm{r}=.240, \mathrm{p}<.01)$ ile anksiyete alt boyutları olan somatik semptomlar ( $\mathrm{r}=.192$, $\mathrm{p}<.01)$ ve sübjektif anksiyete $(\mathrm{r}=.251, \mathrm{p}<.01)$ ile düşük düzeyde pozitif yönde anlamlı ilişki içinde olduğu görülmektedir.

Araştırmada nomofobinin yaş, cinsiyet ve anksiyete tarafından yordanıp yordanmadığının tespit edilmesi amacıyla hiyerarşik regresyon analizi yapılmıştır. Analiz sonuçları Tablo 2'de gösterilmiştir. 
Tablo 2

Nomofobinin yordanmasına ilişkin hiyerarşik regresyon analizi sonuçları

\begin{tabular}{llllllll}
\hline Değişken & $\mathrm{B}$ & $\begin{array}{l}\text { Standart } \\
\text { Hata }\end{array}$ & $\boldsymbol{\beta}$ & $t$ & $p$ & İkili R & Kısmi R \\
\hline Sabit & $\mathbf{7 2 . 5 5 0}$ & $\mathbf{9 . 4 9 2}$ & & $\mathbf{7 . 6 4 3}$ & $\mathbf{. 0 0 0}$ & & \\
Yaş & -.560 & .458 & -.061 & -1.222 & .222 & -.098 & -.064 \\
Kadın & 8.542 & 1.549 & .277 & 5.516 & .000 & .285 & .276 \\
\hline 1.Blok: R=.292; $\mathrm{R}^{2}=.085 ; \Delta \mathrm{R}^{2}=.085 ; \mathrm{F}_{(2,369)}$ & $=17.171 ; \mathrm{p}<.001$ & & & \\
\hline Sabit & $\mathbf{6 4 . 5 1 8}$ & $\mathbf{9 . 4 3 4}$ & & $\mathbf{6 . 8 3 9}$ &. $\mathbf{0 0 0}$ & & \\
Yaş & -.437 & .446 & -.049 & -.980 & .328 & -.098 & -.051 \\
Kadın & 8.323 & 1.506 & .270 & 5.529 & .000 & .285 & .277 \\
SS & -.127 & .214 & -.049 & -.594 & .553 & .192 & -.031 \\
SA & .431 & .128 & .275 & 3.371 & .001 & .251 & .173 \\
\hline
\end{tabular}

2.Blok: $\mathrm{R}=.376 ; \mathrm{R}^{2}=.141 ; \Delta \mathrm{R}^{2}=.056 ; \mathrm{F}_{(2,367)}=12.042 ; \mathrm{p}<.001$

Tablo 2'de yaş, cinsiyet ve anksiyetenin nomofobiyi ne kadar yordadığı görülmektedir. Buna göre birinci blokta analize sokulan yaş ve cinsiyet değişkenleri nomofobiyi anlamlı bir şekilde yordamaktadır $\left(\mathrm{F}_{(2,369)}=17.171, \mathrm{p}<.001 ; \mathrm{R}^{2}=.085\right)$. Birinci blokta girilen sosyo-demografik değişkenlerden yaşın nomofobiyi anlamlı bir şekilde yordamadığı, cinsiyetin ise anlamlı bir şekilde yordadığı ve her iki değişkenin nomofobiye ilişkin varyansın \%8.5'ini açıkladığı görülmektedir. İkinci blokta analize dahil edilen anksiyete alt boyutlarının (somatik semptomlar ve sübjektif anksiyete) nomofobiyi anlamlı bir şekilde yordadığı görülmektedir $\left(\mathrm{F}_{(2,367)}=12.042, \mathrm{p}<.001 ; \mathrm{R}^{2}=.141 ; \Delta \mathrm{R}^{2}=.056\right)$. İkinci blokta analize dahil edilen anksiyete alt boyutlarının modele katkıları ayrı ayrı incelendiğinde sübjektif anksiyetenin nomofobiyi anlamlı bir şekilde yordadığı, somatik semptomların ise anlamlı bir şekilde yordamadığı görülmektedir. Her iki alt boyutun nomofobiye ilişkin toplam varyansın \%5.6'sını açılkladığı görülmektedir. Oluşturulan model bir bütün olarak değerlendirildiğinde modele girilen değişkenlerin (Cinsiyet, Yaş, sübjektif anksiyete ve somatik semptomlar) nomofobiye ilişkin toplam varyansın \%14.1'ini açıkladığı görülmektedir.

\section{SONUÇ, TARTIŞMA VE ÖNERİLER}

Nomofobi teknolojinin beraberinde getirdiği güncel sorunlardan biri olduğundan üzerinde durulan bir olgudur. Sorunun görece yeni olması, nomofobi ile ilgili yapılan araştırmalarda bir sınırlılık oluşturmaktadır. Çoğu insanın neredeyse elinden düşürmediği akıllı telefonların yarattığı bu sorunun ve ilişkili olduğu değişkenlerin araştırılması, bu yeni olgunun anlaşılması açısından önemlidir. Bu araştırmada yaş ve cinsiyet gibi sosyo-demografik değişkenlerle anksiyete gibi bir ruh sağlı̆̆ probleminin 
nomofobiyi yordayıcılığı araştırılmaktadır. Araştırmada cinsiyetin ve sübjektif anksiyetenin nomofobiyi anlamlı bir şekilde yordadığı tespit edilmiştir.

Araştırmanın birinci araştırma sorusu yaş ve cinsiyetin nomofobiyi anlamlı bir şekilde yordayıp yordamadığı şeklindedir. Yürütülen regresyon analizi sonucunda cinsiyetin, başka bir ifade ile kadın olmanın nomofobiyi anlamlı bir şekilde yordadığı, buna karşın yaşın nomofobinin anlamlı bir yordayıcısı olmadığı tespit edilmiştir. Cinsiyet değişkeni açısından alanyazın incelendiğinde, araştırmanın bulgusuna benzer şekilde nomofobi düzeyinin erkeklere göre kadınlarda anlamlı bir şekilde daha fazla olduğunu gösteren araştırmaların (Burucuoğlu, 2017; Erdem ve diğ., 2017; Turan ve İşçitürk, 2018) olduğu görülmektedir. Bununla birlikte, alan yazında nomofobinin cinsiyete göre anlamlı bir şekilde farklılaşmadığını gösteren araştırmalar da bulunmaktadır (Adnan ve Gezgin, 2016; Apak ve Yaman, 2019). Araştırmalar (Aktaş ve Yılmaz, 2017; Erdem ve diğ., 2016) kadınların erkeklerden daha fazla akıllı telefonla vakit geçirdiklerini göstermektedir. Literatürde nomofobinin günlük telefon kullanma süresi (Yazıcı-Kabadayı ve Kabadayı, 2020), telefonu sık sık kontrol etme ve mobil internet kullanma oranı (Gezgin ve diğ., 2017) ile pozitif ilişkili olduğu görülmektedir. Araştırmanın bulgusu literatür ışığında değerlendirildiğinde, kadınların akıllı telefonla daha fazla zaman geçirmeleri ve gerek internet kullanma amaçlı gerek başka amaçlarla telefonlarını sık sık kontrol etmelerinin nomofobinin gelişmesinde kadınlarda erkeklere oranla daha fazla etkili olduğu söylenebilir. Yaş değişkeni açısında alanyazın incelendiğinde araştırmanın bulgusuna benzer şekilde yaş değişkeninin nomofobiye göre anlamlı şekilde farklılaşmadığını gösteren çalışmaların (Güllüce, Kaygın ve Börekçi, 2019; Ramazanoğlu, 2020) olduğu görülmektedir. Buna karşın alanyazında nomofobinin yaş değişkenine göre anlamlı şekilde farklılaştığını gösteren çalışmaların da (Arslan, Tozkoparan ve Kurt, 2019; Yıldız, Çengel ve Alkan, 2020) olduğu görülmektedir. Bu çalışmada yaş değişkeninin nomofobinin ortaya çıkmasında önemli bir etkiye sahip olmamasının nedenlerinden biri, araştırmaya katılan katılımcıların yaşlarının birbirine yakın olması olabilir. Ayrıca günümüzde her yaştan gencin akıllı telefona sahip olması, başka bir ifade ile akıllı telefona sahip olma yaşının olmaması yaş değişkeninin anlamlı bir etkiye sahip olmamasında etkili olabilir.

Araştırmanın ikinci alt problemi anksiyetenin nomofobiyi yordayıp yordamadığı şeklindedir. Araştırmada kullanılan anksiyete ölçeğinin alt boyutlarından sübjektif anksiyetenin nomofobiyi pozitif yönde anlamlı bir şekilde yordadığı buna karşın somatik semptomların nomofobiyi anlamlı bir şekilde yordamadığı tespit edilmiştir. Başka bir ifade ile nomofobinin oluşmasında sübjektif anksiyetenin anlamlı bir etkiye sahip olduğu tespit edilmiştir. Alanyazın incelendiğinde, araştırmanın sonucunu destekleyen araştırmaların (Demirci ve diğ., 2015; Elhai ve diğ., 2016; Kara ve diğ., 2019; Veerapu ve diğ., 2019) olduğu görülmektedir. Anksiyete gelecekteki olası bir tehlikeye karşı duyulan genel bir endişe hali olarak tanımlanmaktadır ve bireyde tehdit oluşturan durumdan kaçma eğilimini ortaya çıkarabilmektedir (Butcher ve diğ., 2013). Uzun süreli endişe bireyin ruh sağlığı üzerinde olumsuz etkiler yarattığından birey bu duyguya uzun süre dayanamamakta bu endişeden kurtulmak için farklı alanlara yönelebilmektedir. Hemen 
hemen her bireyin elinde bulunan ve sahip olduğu özelliklerle her kesimden insanları cezbeden akıllı telefonlar, bu yoğun endişeden kurtulmak için güvenli bir liman olabilmektedir. Bu bağlamda, anksiyetenin nomofobinin gelişmesi üzerinde etkili olduğu söylenebilir.

Sonuç olarak teknolojinin insanoğlunun hayatına girmesiyle ortaya çıkan sorunlardan biri olan nomofobinin cinsiyet ve sübjektif anksiyete tarafından anlamlı bir şekilde yordandığı, her iki değişkenin nomofobinin anlamlı bir açıklayıcısı olduğu görülmektedir. Buna karşın yaş değişkeninin nomofobinin ortaya çıkmasında anlamlı bir etkiye sahip olmadığı görülmektedir.

Araştırmanın bazı sınırlılıkları bulunmaktadır. Araştırma üniversite öğrencileri üzerinde gerçekleştirilmiştir. Bu nedenle araştırmadan elde edilen sonuç ancak benzer örneklemlere genellenebilir. Araştırmada aynı zamanda araştırmacılara yönelik bazı önerilerde bulunulmuştur. Araştırma farklı örneklemler (ergen ve yetişkin) üzerinde tekrarlanarak araştırmanın sonuçları test edilebilir. Araştırmada örneklemin yaşları birbirine yakın olduğu için yaş değişkeninin etkisi tam olarak tespit edilememiş olabilir. Bu nedenle farklı yaşlardaki bireylerin nomofobi düzeyleri karşılaştırılarak yaşın etkisi tespit edilebilir. Alanda çalışan uzmanlar (psikolojik danışman, pskolog ve psikiyatristler) anksiyetenin nomofobi üzerindeki etkisini göz önüne alarak nomofobi düzeyini düşürmek için anksiyete düzeyini düşürmeye yönelik çalışmalar planlayabilirler. Okullarda çalışan psikolojik danışmanlar planlayacakları nomofobiyi azaltmaya yönelik psiko-eğitim çalışmalarında anksiyetenin etkisini de göz önüne alarak, oturumlarda bu değişkene yer verebilirler.

\section{Kaynaklar}

Adnan, M. ve Gezgin, D. M. (2016). Modern çağın yeni fobisi: Üniversite öğrencileri arasında nomofobi prevalansı. Journal of Faculty of Educational Sciences, 49(1), 141-158.

Aktaş, H. ve Yılmaz, N. (2017). Üniversite gençlerinin yalnızlık ve utangaçlık unsurları açısından akıllı telefon bağımlılığı. International Journal of Social Sciences and Education Research, 3(1), 85-100.

Apak, E. ve Yaman, Ö. M. (2019). Üniversite öğrencilerinde nomofobi yaygınlığı ve nomofobi ile sosyal fobi arasındaki ilişki: Bingöl Üniversitesi örneklemi. Addicta: The Turkish Journal on Addictions, 6, 609-627. doi:10.15805/addicta.2019.6.3.0078

Arslan, H., Tozkoparan, S. B. ve Kurt, A. A. (2019). Öğretmenlerde mobil telefon yoksunluğu korkusunun ve gelişmeleri kaçırma korkusunun incelenmesi. Erzincan Üniversitesi Eğitim Fakültesi Dergisi, 21(3), 237-256.

Beck, A. T., Epstein, N., Brown, G. ve Steer, R. A. (1988). An inventory gor measuring clinical anxiety: Psychometric properties. Journal of Consulting and Clinical Psychology, 56, 893-897. doi: 10.1037/0022-006X.56.6.893 
Bhattacharya, S., Bashar, M. A., Srivastava, A. ve Singh, A. (2019). Nomophobia: No Mobile PHone PhoBIA. Journal of Family Medicine and Primary Care, 8(4), 1297-1300. doi:10.4103/jfmpc.jfmpc_71_19

Bian, M. ve Leung, L. (2014). Linking loneliness, shyness, smartphone addiction symptoms, and patterns of smartphone use to social capital. Social Science Computer Review, 1-19.

Bivin, J. B., Mathew, P., Thulasi, P. C. ve Philip, J. (2013). Nomophobia-do we really need to worry about? Reviews of Progress, 1(1), 1-5.

Bourne, E. J. (2010). The anxiety and phobia workbook. (Fifth edition). New York: MJF Books.

Bragazzi, N. L. ve Del Puente, G. (2014). A proposal for including nomophobia in the new DSM-V. Psychology Research and Behavior Management, 7, 155. https:// doi.org/10.2147/prbm.s41386.

Burucuoğlu, M. (2017). Meslek yüksekokulu öğrencilerinin nomofobi düzeyleri üzerinde bir araştırma. Karabük Üniversitesi Sosyal Bilimler Enstitüsü Dergisi, 7(2), 482-489.

Butcher, J. N., Mineka, S. ve Hooley, J. M. (2013). Anormal psikoloji. (Çev. Okhan Gündüz). İstanbul: Kaknüs yayınları.

Büyüköztürk, Ş. (2014). Sosyal bilimler için veri analizi el kitabı: İstatistik, araştırma deseni, SPSS uygulamaları ve yorum. Ankara: Pegem Akademi.

Clayton, R. B., Leshner, G. ve Almond, A. (2015). The extended iSelf: The impact of iPhone separation on cognition, emotion, and physiology. Journal of Computer-Mediated Communication, 20, 119-135.

Çokluk, Ö., Şekercioğlu, G. ve Büyüköztürk, Ş. (2012). Sosyal bilimler için çok değişkenli istatistik: SPSS ve LISREL uygulamaları. Pegem Akademi.

Demirci, K, Akgönül, M., Akpınar, A. (2015). Relationship of smartphone use severity with sleep quality, depression, and anxiety in university students. Journal of Behavioral Addictions, 4(2), 85-92.

Durak, H. Y. (2018). What would you do without your smartphone? Adolescents' social media usage, locus of control, and loneliness as a predictor of nomophobia. Addicta: The Turkish Journal on Addictions, 5(2),1-15.

Durmuş, B., Yurtkoru, S. ve Çinko, M. (2011). Sosyal bilimlerde SPSS ile veri analizi (4. bs.). Beta Yayınevi: İstanbul.

Elhai, J. D., Levine, J. C., Dvorak, R. D. ve Hall, B. J. (2016). Fear of missing out, need for touch, anxiety and depression are related to problematic smartphone use. Computers in Human Behavior, 63, 509-516. doi:10.1016/j.chb.2016.05.079

Erdem, H., Kalkın, G., Türen, U. ve Deniz, M. (2016). Üniversite öğrencilerinde mobil telefon yoksunluğu korkusunun (nomofobi) akademik başarıya etkisi. Süleyman Demirel Üniversitesi İktisadi ve İdari Bilimler Fakültesi Dergisi, 21(3), 923-936.

Erdem, H., Türen, U. ve Kalkın, G. (2017). Mobil telefon yoksunluğu korkusu (nomofobi) yayılımı: Türkiye'den üniversite öğrencileri ve kamu çalışanları örneklemi. Bilişim Teknolojileri Dergisi, 10(1), 1-12. 
Gezgin D. M, Şahin, Y. L. ve Yıldırım, S. (2017). Sosyal ağ kullanıcıları arasında nomofobi yaygınlığının çeşitli faktörler açısından incelenmesi. Eğitim Teknolojisi Kuram ve Uygulama, 7(1), 1-15.

Gezgin, D. M. (2017). Exploring the influence of the patterns of mobile internet use on university students' nomophobia levels. European Journal of Education Studies, 3(6), 29-53. doi:10.5281/zenodo.572344

Gezgin, D. M. Hamutoglu, N. B., Sezen-Gultekin, G. ve Gemikonakli, O. (2018). Relationship between nomophobia and fear of missing out among Turkish university students. Cypriot Journal of Educational Science, 13(4), 549-561.

Gezgin, D. M., Hamutoglu, N. B., Sezen-Gultekin, G. ve Ayas, T. (2018). The Relationship between Nomophobia and Loneliness among Turkish Adolescents. International Journal of Research in Education and Science, 4(2), 358-374.

Gezgin, D. M., Şumuer, E., Arslan, O. ve Yıldırım, S. (2017). Nomophobia prevalence among pre-service teachers: A case of Trakya University. Trakya Üniversitesi Eğitim Fakültesi Dergisi, 7(1), 86-95.

Güllüce, A. Ç., Kaygın, E. ve Börekçi, N. E. (2019). Üniversite öğrencilerinin nomofobi düzeyi ile öznel iyi olma durumları arasındaki ilişkinin belirlenmesi: Ardahan örneği. Hacettepe Üniversitesi İktisadi ve İdari Bilimler Fakültesi Dergisi, 37(4), 651-673.

Hoşgör, H., Tandoğan, Ö. ve Gündüz-Hoşgör, D. (2017). Nomofobinin günlük akıllı telefon kullanım süresi ve okul başarısı üzerindeki etkisi: sağlık personeli adayları örneği. Akademik Sosyal Araştırmalar Dergisi, 5(46), 573-595.

Hwang, K. H, Yoo, Y. S. ve Cho, O. H. (2012). Smartphone overuse and upper extremity pain, anxiety, depression, and interpersonal relationship among college students. The Journal of the Korea Contents Association. 12(10), 365-375.

Kaplan-Akıllı, G. ve Gezgin, D. M. (2016). Üniversite öğrencilerinin nomofobi düzeyleri ile farklı davranış örüntülerinin arasındaki ilişkilerin incelenmesi. Mehmet Akif Ersoy Üniversitesi Eğitim Fakültesi Dergisi, 40, 51-69.

Kara, M., Baytemir, K. ve Inceman-Kara, F. (2019). Duration of daily smartphone usage as an antecedent of nomophobia: exploring multiple mediation of loneliness and anxiety. Behaviour \& Information Technology, 1-14. doi:10.1080/0144929X.2019.1673485.

Kayış, A. (2014). Güvenirlik Analizi. Ş Kalaycı (ed.), SPSS uygulamalı çok değişkenli istatistik teknikleri (s. 403-419). (6. Baskı). Ankara: Asil Yayıncılık.

King, A. L., Valença, A. M., Silva, A. C., Baczynski, T., Carvalho, M. R. ve Nardi, A. E. (2013). Nomophobia: Dependency on virtual environments or social phobia? Computers in Human Behavior, 29(1), 140-144.

Kneidinger-Mueller, B. (2019). When the smartphone goes offline: A factorial survey of smartphone users' experiences of mobile unavailability. Computers in Human Behavior, 98, 1-10.

Konan, N., Durmuş, E., Türkoğlu, D. ve Ağıroğlu Bakır, A. (2018). How is smartphone addiction related to interaction anxiety of prospective teachers? Education Sciences, 8, 186. doi:10.3390/educsci8040186 
Küçüksille E. (2014). Çoklu doğrusal regresyon modeli. Ş Kalaycı (Ed), SPSS uygulamalı çok değişkenli istatistik teknikleri (s. 47-66) içinde. Ankara: Asil Yayıncılık.

Lee, K. E., Kim, S. H., Ha, T. Y., Yoo, Y. M., Han, J. J., Jung, J. H. ve Jang, J. Y. (2016). Dependency on Smartphone use and its association with anxiety in Korea. Public Health Reports, 131, 411-419.

Öz, H. ve Tortop, H. S. (2018). Üniversite okuyan genç yetişkinlerin mobil telefon yoksunluğu korkusu (Nomofobi) ile kişilik tipleri arasındaki ilişkinin incelenmesi. e-Jurnal of New Media / Yeni Medya Elektronik Dergi - eJNM, 2(3),146-159.

Pavithra, M. B. ve Madhukumar, S. (2015). A study on nomophobia-mobile phone dependence, among students of a medical college in Bangalore. National Journal of Community Medicine, 6(3), 340-344.

Pivetta, E., Harkin, L., Billieux, J., Kanjo, E. ve Kuss, D. J. Problematic smartphone use: An empirically validated model. Computers in Human Behavior, 100, 105-117.

Ramazanoğlu, M. (2020). Öğretmen adaylarinin nomofobi düzeylerinin belirlenmesi. Ekev Akademi Dergisi, 81, 247-264.

SecurEnvoy, (2012). 66\% of the population suffer from Nomophobia the fear of being without their phone. https://www.securenvoy.com/en-gb/blog/66-population-suffernomophobia-fear-being-without-their-phone. 26.07.2020 tarihinde erişildi.

Sezer, Ö. ve Ylldırım, O. (2020). The relationship between nomophobia and trait anxiety, basic psychological needs, happiness in adolescents. International Journal of Human Sciences, 17(2), 535-547.

Sırakaya, M. (2018). Ön lisans öğrencilerinin nomofobi düzeylerinin akıllı telefon kullanım durumlarına göre incelenmesi. Mersin Üniversitesi Eğitim Fakültesi Dergisi, 14(2), 714727.

Suadiye, Y. ve Aydın, A. (2009). Anksiyete bozukluğu olan ergenlerde bilişsel hatalar. Klinik Psikiyatri Dergisi, 12(4), 172-179.

Turan, E. Z. ve İşçitürk, G. B. (2018). İlahiyat fakültesi öğrencilerinin nomofobi düzeylerinin çeşitli faktörler açısından incelenmesi. OPUS Uluslararası Toplum Araştırmaları Dergisi, 9(16), 1931-1950. doi:10.26466/opus.461523

Türen, U., Erdem, H. ve Kalkin, G. (2017). Mobil telefon yoksunluğu korkusu (nomofobi) yayılımı: Türkiye'den üniversite öğrencileri ve kamu çalışanları örneklemi. International Journal of Informatics Technologies, 10(1), 1-12. doi: $10.17671 /$ btd.30223

Ulusoy, M., Şahin, N. ve Erkmen, H. (1996). Turkish version of The Beck Anxiety Inventory: Psychometrik properties. Journal of Cognitive Psychotherapy, 12(2), 163-172.

Uysal, Ş., Özen, H. ve Madenoğlu, C. (2016). Social phobia in higher education: the influence of nomophobia on social phobia. The Global eLearning Journal, 5(2), 1-8.

van Deursen, A. J., Bolle, C. L., Hegner, S. M. ve Kommers, P. A. (2015). Modeling habitual and addictive smartphone behavior: The role of smartphone usage types, emotional intelligence, social stress, self-regulation, age, and gender. Computers in Human Behavior, 45, 411-420. 
Veerapu, N., Philip, R. K. B., Vasireddy, H., Gurrala, S. ve Kanna, S. T. (2019). A study on nomophobia and its correlation with sleeping difficulty and anxiety among medical students in a medical college, Telangana. International Journal of Community Medicine And Public Health, 6(5), 2074-2076.

Yaman, Z. ve Kavuncu, B. (2019). Üniversite öğrencilerinin sosyal gelişmeleri kaçırma korkusunun ve sosyal ağ kullanım amacının nomofobi düzeyine etkisi. Sosyal Bilimler Araştırmaları Dergisi, 14(2), 555-570.

Yazıcı-Kabadayı, S. ve Kabadayı, F. (2020). Nomofobiyi açıklamada psikolojik ihtiyaçlar ve günlük telefon kullanım süresinin rolü. Online Journal of Technology Addiction and Cyberbullying, 7(1), 1-20.

Yildirim, C. ve Correia A. P. (2015). Exploring the dimensions of nomophobia: Development and validation of a self-reported questionnaire. Computers in Human Behavior, 49, 130-137.

Yildirim, C., Sumuer, E., Adnan, M. ve Yildirim, S. (2016). A growing fear: Prevalence of nomophobia among Turkish college students. Information Development, 32(5), 13221331.

Yildiz Durak, H. (2019). Investigation of nomophobia and smartphone addiction predictors among adolescents in Turkey: Demographic variables and academic performance. The Social Science Journal, 56(4), 492-517.

Yıldız, E. P., Çengel, M. ve Alkan, A. (2020). Öğretmenlerin nomofobi düzeylerinin demografik özelliklerine ve akıllı telefon kullanım alışkanlıklarina göre incelenmesi. OPUS Uluslararası Toplum Araştırmaları Dergisi, 15(1), 5096-5120. 
Bu çalışma için etik kurul izni 04/09/2020 tarih ve 2020/08 sayılı İstanbul Sebahattin Zaim Üniversitesi Rektörlüğü Etik Kurulu'ndan alınmıştır.

\section{Araştırmacıların Makaleye Katkı Oranı Beyanı:}

1. yazar katkı oranı: $\% 50$

2. yazar katkı oranı: $\% 50$

Çıkar Çatışması Beyanı:

Yok.

Finansal Destek veya Teşekkür Beyanı

Bu çalışma için herhangi bir kurumdan finansal destek alınmamıştır. 